\title{
THE EFFECTS OF LEARNING MOTIVATION TOWARDS STUDENT'S LEARNING ACHIEVEMENT IN ENGLISH
}

\author{
Suroso \\ Universitas Pamulang \\ dosen00722@unpam.ac.id
}

\begin{abstract}
English is still regarded as a difficult lesson by most of the students, so student's learning achievement in English is low. The Purpose of this research determines The effects of Learning Motivation Towards Student's Learning Achievement in English at Kota Tangerang Selatan. The research method used is survey method. Sample size as many as 90 students from SMP Negeri 4 represents International Designed Rating School, SMP Negeri 11 represents National Rating School and SMP Negeri 6 Kota Tangerang Selatan. Data Collection carried out by interview, giving questionnaires and carrying out learning achievement in English test. The research is conducted in May 2012.Research results show learning motivation variable has significant effects towards students' learning achievement in English. Research results state there is the effects of learning motivation towards student's learning achievement in English of class VIII SMP Negeri Kota Tangerang Selatan From the research results, it can be concluded that each increase in learning motivation by one unit will be followed by changing in one unit of student achievement in English as well. Suggestions that can be conveyed are to increase learning motivation, many things can be done, including by giving awards to outstanding students.
\end{abstract}

Keywords: Learning Achievement in English, Learning Motivation.

\section{INTRODUCTION}

English is a means to communicate orally and in writing. Communicating is to understand and communicate information, thoughts, and feelings, develop science, technology, as well as culture. Ability to communicate in the sense of an intact is the ability of the discourses, namely the ability to understand and/or produce spoken text and / or written to be realized in the four aspects of language skills, namely listening, speaking, reading and writing. The fourth skills are used to respond to or create a discourse in public life.

Therefore, English subject is directed to develop these skills for graduates are able to communicate and discourse in English at a certain level of literacy. In
Indonesia, English is not regarded as a second language but a foreign language. Methods of teaching and learning English as a second language and foreign language are slightly different. In the second language classroom, an English teacher does not have to use many illustrations, images, or videos while on a foreign language class, students are not familiar with the English language altogether. Teachers have to use a lot of illustrations, pictures, and video and sound recordings to help student's listening, speaking, reading, and writing in English well.

The introduction of internet technology has helped the experience of teaching and learning English becomes easier. The teachers can communicate and share their experiences with other teachers, 
and download games, grammar exercises and lesson plans. Similarly, the availability of English language learning software has helped many English learners around the world to master the language better and faster.

In Kota Tangerang Selatan, English is still regarded as a difficult lesson by most of the students, so student's learning achievement in English is low. The low learning achievement in English demonstrates the process of learning English, learning habit and learning motivation are not optimal. The result of student's learning achievement in English each year has not achieved a satisfactory increase in achievement. These results show the tendency of learning achievement in English is low.

There are several problems in the stage of preparation, implementation and post-learning activities to teach English. Two of these problems among others, are learning motivation, and learning achievement in English.

Motivation is one of the most important prerequisite in learning. motivation is defined as a change of power in own self private person who is marked by the effective encouragement and reactions in an attempt to reach the goal. Djiwandono (2006:328). This definition contains three issues:(a) motivation starts with an energy change in a person (b) motivation is marked by affective. The principles of learning motivation :as a driving that encourages learning activities, the main motivation is more intrinsic than extrinsic motivation in learning, motivation in the form of compliment is better than punishment, motivation is closely related to the needs of in learning, motivation can be fostered optimism in learning, achievement gave birth within to learn. The function of learning motivation as the driving act, and steering act. (Syaiful Bahri Djamarah, 2008: 153-157).
I.S.P.Nation \& John Macalister (2010: 39) seem that in motivation, as much as possible, the learner should be interested and excited about learning the language and they should come to valuate learning.

Motivation is seen as a mental impulse that moves and directs human behavior, including learning behavior. In motivation contained the desire to activate, move, channel and direct attitudes and behavior in individual learning.(jurnal.upi.edu,2011:Vol.12 No. 1 , hlm, 92).

From the above description, a person is suspected that the strong motivation to excel on the views and confidence depends on himself that he will be able to achieve what will be sought to be achieved, for in other words, motivation indicate a choice of experience that will be achieved or avoided and the degree of effort which will be used.

Researcher argues that motivation is complex, the strength, encouragement needs statement, or other mechanisms that initiate and maintain voluntary activity directed at the achievement of personal goals. person's motivation is dependent on the size of the motive, this is because it indicates that the motive of an impulse arising from inside a person who causes such an act would do something.

Learning motivation in this research is any encouragement either from outside (external) and which grew out of the student (internal), which directs attention, relevance and confidence building, and creating learning satisfaction in order to acquire the knowledge, attitudes, and skills.

Next on the rationale above theoretical framework, that learning motivation in this research is a complex statement within an organism that directs behavior toward a goal or stimulants which is characterized by indicators:(1)the desires and wishes succeed,(2) the encouragement and 
learning needs, (3) the hopes and dreams of the future,(4)the appreciation of learning,(5) the interest in learning activities ,(6) the existence of a higher learning environment that enables one the student can learn well.

Test of motivation in this research will use a Likert scale based on the characteristics of the learning motivation that described in dimension then explained to be some indicators of measurement items. High scores obtained from Likert scale, showed a high value learning motivation to learn English, otherwise a low score indicates low motivation to learn English.

Based on the above description, it can be concluded that the definition of learning motivation in this research is a spirit from within the individual against all physical and mental activity that led to encourage students in learning activities, to filter the type of activities that wish to follow and make students, and direct the student's behavior. There are five dimensions that used in this research that is internal and external encouragement, actualization, psychological conditions, needs, and motor drive.

From the above explanation, the writer argues that learning motivation is sourced from within the individual also achieve a success in learning, and therefore, learning motivation is a very important role in achieving a success because it achieves a success of a person caused the existence of self-motivation in order to reach a good learning achievement.

Learning is process of development of human life. By learning, people perform qualitative changes in individuals so that their behavior develops. All the activities and achievements of human life is learning achievement.

Human also live in and work according to what we have learned. Learning is not just experience. Learning is a process, not an achievement. Because of that learning taken place in an active and integrative by using various forms of action to achieve a goal. ( Wasty Soemanto,2006: 104-105).

Learning achievement is defined by a student's mastery of knowledge obtained after following the learning the learning activities during the period of time.

Assessment is a series of activities to acquire, analyze, and interpret the process the process and learning achievement of students who carried out systematically and continuously so that it becomes meaningful information in decision-making to determine the level of success achievement of competencies that have been determined. As is the assessment technique is the way in which to obtain information about processes and products of learning carried out by learner. Form instrument by (1) Writing test: could be an essay test/description, multiple choice, filling, etc. to match,(2) Oral test: form a list of question (3) performance can be an identification test, simulation test, quotes of the work product, quotation test of work procedure or quotation test of work procedures and products. (Standar Isi dan Standar Lulusan Tingkat SMP \& MTs 2006:827-828)

Purwanto (2009: 34), stated that learning achievement is the changes in student's behavior due to learning. The change is in a process of learning teaching to achieve educational goals.

A person's learning achievement is in accordance with the level of success of something in teach subject which is stated in the form of mark or report book for each subject after experiencing the teaching and learning process. Student achievement can be known after an evaluation. The results of evaluations can show about the high or low student achievement.(jurnal.upi.edu,2011:Vol.12. No.1,hal,92). 
Activities of the student learning through student the learning objects or resources. Learning experiences can be selected according to with the competence can be obtained in the classroom and outside the classroom. The form can be demonstrated activity, practice, simulate, conducting experiments, analyzing, applying

finding, observing, researching, analyzing, etc. Which are not teacher student interaction activities such as listening to a description of teachers discussion under the guidance of teachers? (Standar Isi dan Standar Lulusan Tingkat SMP \& MTs, 2006:834).

Learning achievement in English in this research is the ability to obtain, process, and produce English as a result of experience and interaction with the environment which includes listening skills, speaking, 'reading, and writing and performance that involves the social aspects of language in interacting with others. The ability to obtain the language refers to the area of cognition, processing the information obtained as the affective area, and produce English as psychomotor area.

Based KTSP (Curriculum Education Level Unit), competencies that must be mastered by student's class VIII of SMPN, after attending English learning activities, teaching materials that will be tested in this research in is: Transactional and interpersonal text, Descriptive text, Announcement text,, Invitation and Short Message, The recount text, Learning and Narrative text.

Based on literature review above, it can be shown that in the learning process, the role of individuals who learn a very great influence on learning achievement in English. Therefore, in the efforts to increase result of learning achievement in English, the factors originating from outside the individual self who are studying should be directed to support and activate factors that exist within the individual learners. Thus, behavioral changes that occurred due to the activity of the individual. In connection with these results in this research is the students' learning achievement is the change in student behavior after reaching the standard of competence and basic competence in the activities of the learning teaching process, which is shown value of learning achievement test.

Assessment of learning achievement is an educational activity related to make decisions regarding the achievement of competencies or student's learning achievement who follows the learning process. That is why, we need reliable data as the information on which to base decisions. The decision relates to the success of learners in achieving a competency. Thus, assessment of learning achievement is one of the pillars in the implementation of the KTSP.

Based on the of thought and empiric phenomena mentioned above, the writer is interested to conduct research with the title: 'The Effect of Learning Motivation towards Student's Learning Achievement.(Survey at SMP Negeri Kota Tangerang Selatan).

Then based on the background and above problems, the issues examined in this research is formulated as follows:

1).Is there any effect of learning motivation (X) towards student's learning achievement in English (Y) of SMPN Kota Tangerang Selatan?

2).How large is the contribution of Learning motivation (X) towards student's learning achievement in English (Y) of SMPN Kota Tangerang Selatan?

$3)$.How is the model of regression between learning motivation (X) towards learning achievement in English (Y) of SMPN Kota Tangerang Selatan? 
In order to be more focused this research, the authors will limit as follows:

1).Learning motivation is internal and external encouragement that drives one students to learn because of the desires, needs, hopes, and ideals, self -actualization, interest in learning, comfortable environment, as well as information about strength, passion, effort, psychological condition, drive, passion, mental capabilities, inherent in a person, motor drive, direction and follow up after learning.

2). Learning achievement in English is defined as mastery of knowledge by a student who obtained the student after attending a learning process that has be done within a certain period, usually stated by a value appropriate to the ability given by the teacher. It is obtained from learning achievement in English test after completing some of the competencies that have been implemented in the teaching and learning activities.

The purpose of this research is to determine:

1).The effect of learning motivation towards student's learning achievement in English of SMPN Kota Tangerang Selatan?

2).How large the effect of learning motivation towards student's learning achievement in English of SMPN Kota Tangerang Selatan?

3). The model of regression between learning motivation towards Learning achievement in English of SMPN Kota Tangerang Selatan?

The result of this research is expected to contribute to the increase in quantity and quality of learning, particularly English, both theoretical and practical for teachers especially
English teachers and students of SMPN Kota Tangerang Selatan as well as readers in general. Benefits of this research in general can be divided into 2, namely:

\section{In Theoretical}

1). This research is expected to encourage teachers to improve their competence, so having a positive impact for the creation of a conducive environment and achieving optimal learning achievement.

2). To provide input and give the teachers that their efforts to improve student's learning achievement in English can be achieved by increasing student's learning motivation.

3).Encouraging teachers to always be innovative, in carrying out the learning process, thereby providing a positive impact on the growth of student's learning motivation in English.

\section{In Practical}

1). Improving learning motivation

2). Growing develop learning motivation to learn English.

3). Increasing student's learning outcomes in English by improving learning motivation in English.

\section{METHOD}

This research carried out by using survey method in SMP Negeri Kota Tangerang Selatan who given to students of the academic year $2011 / 2012$ by object research is class VIII. This research method is used to know the effect of learning motivation $(\mathrm{X})$, and student's learning achievement in English (Y).

According to Arikunto (2002) quoted by Supardi US (First edition:26) stated "Sample is part of population (parts or represents of population that researched) .Further, research samples are class VIII 
consisted of 30 students from SMP Negeri 4 represents of International Designated Rating Schools (RSBI),30 students from SMP Negeri 11 represents of National Rating School (SSN) and 30 students from SMP Negeri 6 represents of National Designated Rating Schools (RSSN) Kota Tangerang Selatan.

Sampling technique by using the method of random sampling quota (Sugiyono, 2007: 77). In its implementation research samples chosen 30,333 \% quota of students from SMP Negeri 4, and 30,333\% quota of students from SMP Negeri 11 as well as 30,333 \% quota of students from SMP Negeri 6 Kota Tangerang Selatan.

The first data collection techniques students' learning motivatio n conducted by using questionnaires. The questionnaire composed in the form of the

attitude scale consisting of five answer choices matter as many as 45 points. Sources of data in this research are students who selected as the research sample.

The second data collection techniques for the variable of learning achievement in English conducted through learning achievement test instruments arranged in the form of multiple-choice test matter as many as 30 points with four answer choices. In this case the data sources are students who selected as respondents.

\section{Learning Motivation}

Dimensions are described into a number of indicators, with a total of 45 questionnaire items. In this case, the instrument of research distributed to 30 students who are not registered as respondents of the research, the test results are further calculated to be the value of validity and reliability as follows:

\section{1). Validity Test}

The variable of learning motivation is arranged in the form of multiple choice questionnaire with five answer choices given to the respondent and then measured through Product Moment. 2).Reliability Test

For reliability test of learning habit instrument calculated by Cronbach's Alpha formula.

\section{Learning Achievement in English}

In this case, the instrument of research distributed to 30 students who are not registered as respondents of the research, the test results are further calculated to be the value of validity and reliability as follows:

\section{1). Validity Test}

Feasibility of research instrument for student learning achievement variables is calculated through formula point of research instruments for student learning achievement variables, this according to the scores obtained for student's learning achievement test, where the answer are in interval 0 (for incorrect answers) and 1 (for the correct answer).

\section{2). Reliability Test}

For reliability test of learning motivation instrument done by Cronbach's Alpha formula.

\section{Data Analysis Techniques}

Data analysis techniques used to obtain

answers to research hypotheses is distinguished in two categories which are:

\section{1). Descriptive Analysis Technique}

Statistical analysis techniques is testing research data, which is done by presenting the data in the form of basic statistical calculations that include a frequency distribution table, histogram, mean value, median, mode, standard deviation.

\section{2). Regression Analysis Techniques}

Regression analysis technique done by some of the requirement tests are: 


\section{Normality Test}

Normality test is done through with the aid SPSS Statistics 17.0 Program. Based on the Kolmogorov-Smirnov test. Based on acceptance criteria, it can be stated to be well standardized value if the value Asymp. Sig. (2-tailed)> a (alpha) . Or obtained, the conclusion that the data used in the research standardized and distribute normally.

\section{Linearity Test}

Linearity of test aims to determine whether two variables that will be charged procedures correlation statistical analysis shows, there is relation, that linear or not. Furthermore, testing steps, using SPSS 17. Decisionmaking method of linearity testing, that is "if the significance of the Linearity > 0.05 then the relation between two variables is not linear, and if the significance of the Linearity $<0.05$ then the relation between two variables stated linear".

\section{Regression Analysis}

After it is believed that the data obtained from the spread of research instruments fulfill the requirements of the analysis, further, conducting, multiple regression analysis using SPSS Statistics 17.0 Program. Multiple linear regression analysis performed to determine the influence of the dependent of the dependent variable towards independent variables.

\section{Hypothesis Test}

To determine the independent variables that most influence on learning achievement in English can be done through the $t_{\text {-test }}$. Through the $t_{\text {-test }}$ can be known the influence of each independent variable that is learning motivation variable in partially. To test the significance of each regression of coefficient hypothesis.

\section{DISCUSSIONS}

\section{Description of Data}

Basically, the research data obtained from the distribution of questionnaire to determine student's learning motivation and learning achievement in English test to reveal a mastery of English.

\section{Data Analysis of Student's Learning Motivation}

From

providing questionnaires to a

variable student's learning motivation for the research sample consisted of 90 students obtained the highest score is 169 and the lowest score is 100. Furthermore mean of student's learning 1 motivation is 129.23 with a standard deviation is 18.211 and supported also by median is 130.50 as well as mode is 135 .

Based on the results of the research can be explained that student's learning motivation, is in the range is quite diverse, some of students are able to establish positive learning motivation and can support the improvement of learning achievement. Whereas, in part of other students still have a bad learning motivation.

The value of research results for the student's learning motivation can be seen more completely in the following table:

Table 1. Descriptive Statistics of
Student's Learning Motivation

Furthermore, the above data can be explained that the student's learning motivation are still in the level of average, to be able to support learning objective, students should try further enhance improve their learning motivation.

Data Analysis of Student's Learning Achievement

After learning achievement test, in

the form of multiple choice to 90 
students

spread

over three schools. Each of the student's answer, with the correct answer given value of 1 and for incorrect answers given value of 0 . From the response, determined range of values between 0 to 100 .

Through the research data obtained the highest score is 100 and the lowest score is 46. Furthermore, mean of student's learning achievement is 78.10 with a standard deviation is 11.830 and supported also by median is 79.00 as well as mode is 79 .

The value of student achievement is in a range that equivalent to student's learning motivation, where student with a good learning motivation level is able to achieve learning achievement optimal enough, while student with a level of learning bad motivation only able to achieve middle-down learning achievement.

More than the existence of learning motivation, as a support learning achievement in English, learning achiev ements is also quite dependent on the students' learning motivation. It also contributes directly towards student's learning achievement. Student with good learning motivation are better able to achieve the best learning achievement. While student with less learning motivation, face obstacles in increasing learning achievement in English.

Furthermore, students learning achievement in English based on the level of student's learning motivation that students have be able to be expressed in the following table:

Table 2. Statistic Descriptive of Students' Learning Achievement

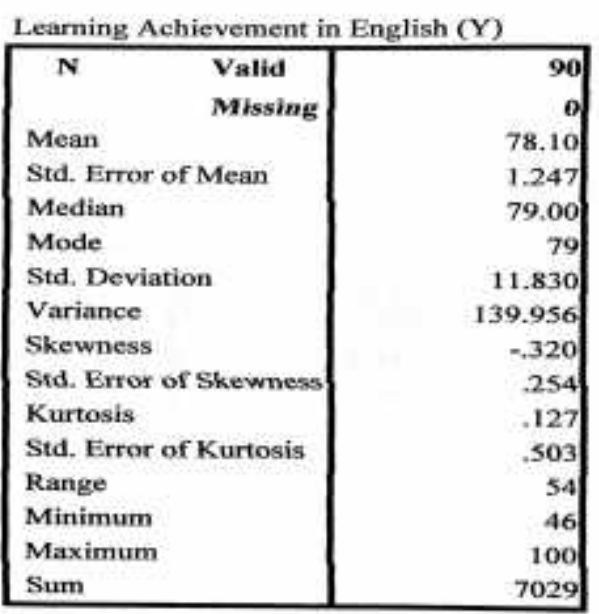

Based on, above table can be explained that the student's learning achievement is in normal condition where students with a high levels of good learning motivation is able to achieve optimal learning achievement. But generally student's learning achievement is in normal, which is supported by learning motivation well.

\section{Requirements Analysis Test}

For obtaining answers to research hypotheses formulated above. Then analysis is done by using the regression methods. Prior to statistical analysis carried out, first tested the requirements which include:

\section{1). Normality Test}

As described in Chapter III about the research methodology that prior to the testing hypothesis, first carried out testing requirements analysis. Requirements that must be fulfilled in testing analysis in the research include sample of normality test with error estimates.

To test whether or not sample of normal, is used Liliefors test (Kolmogorov-Sumirnov) at $\alpha=0,05$. significance level. The purpose of the requirement normality test is to determine whether the research samples 
are taken from that normally distributed population or not.

\section{a. Normality Test}

From the calculation, the estimated error normality test below shows that the variable $\mathrm{X}$ towards $\mathrm{Y}$ derived from normally distributed population as follows:

\section{Table 3. Tests of Normality}

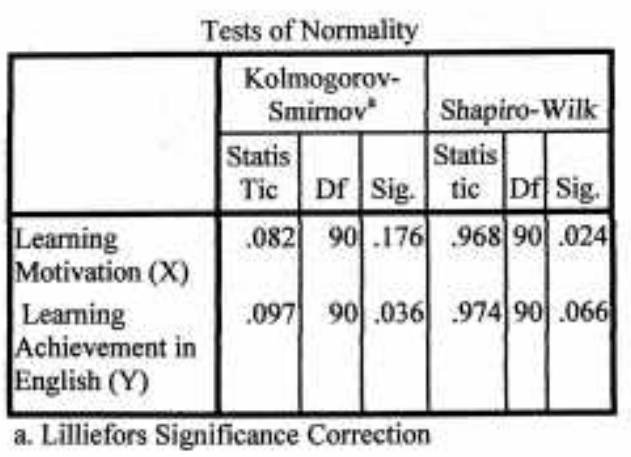

Based on the result data the research, concluded that variable $\mathrm{X}$ towards Y derived from normally distributed population, where a significant value, $0.176>0,05$.

\section{b. Linearity Test}

Testing linearity in this research, is used the following hypothesis;

$\mathrm{H} 0$ :regression line of relation between variables $\mathrm{X}$ and $\mathrm{Y}$

H1: regression line of relation variables

$\mathrm{X}$ and $\mathrm{Y}$ are not linearly

Calculations conducted by SPSS 17. Decision-making methods to testing Linearity of that is "if significance, in Linearity (sig) $>0.05$ then the relation between two variables is not linear, and if the significance, in Linearity (sig) $<0.05$ then the relation between two variables stated linear.

Linearity Test of Learning Motivation (X) towards Learning Achievement in English (Y)
Calculations, testing of Linearity of the regression line, relation between the variables $\mathrm{X}$ with $\mathrm{Y}$ can be seen in the following table:

\section{Table 4. Linearity Test $X$ towards} Y

On the table above shows that the value in the Sig column, Deviation from Linearity line be known the significance of the Linearity as many as 0.406 because the significance is more than 0.05 then the relation between the variables $\mathrm{X}$ towards $\mathrm{Y}$ stated linear.

\section{Research Hypothesis Test}

1.There is Significance Effects of learning motivation (X) towards student's learning achievement in English (Y).

\section{Correlation Coefficient}

Thus hypothesis to be tested are:

$\mathrm{H}_{0} \quad: \rho=0$

$\mathrm{H}_{1} \quad: \mu>0, \rho \neq 0$

The situation is informed $\mathrm{H}_{\mathbf{0}}$ (null hypothesis) there is no effect of learning motivation towards student's learning achievement in English, versus the alternative $\mathrm{H}_{1}$ (alternative hypothesis) that states there is effect of learning motivation towards student's learning achievement in English.

Hypothesis testing done by using regression analysis technique and simple correlation. Testing criteria based through the following requirements:

Reject $\mathrm{H}_{\mathrm{o}}$ and accept $\mathrm{H}_{1}$ if $\mathrm{F}_{\text {count }}>\mathrm{F}_{\text {table }}$

Reject $\mathrm{H}_{\mathrm{o}}$ and accept $\mathrm{H}_{1}$ if $\mathrm{F}_{\text {count }}>\mathrm{F}_{\text {table }}$

Table 5. Correlation Coefficient and Coefficient Determination 


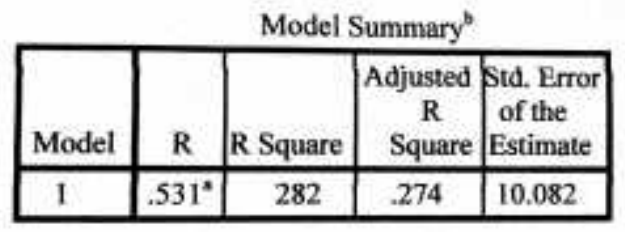

Based on the summary table is obtained correlation coefficient $\mathrm{R}$ $=0,531$ this coefficient informs that student's learning motivation has contribution towards student's learning achievement in English. Further, The coefficient of determination $\mathbf{R}^{2}=0,282$ which informs that $28,2 \%$ learning motivation gives contribution towards the student's learning achievement in English. The higher student's learning motivation will be more optimal learning achievement that can be achieved.

Beyond learning motivation variable, confirmed there are variety of other variables that have significant effect on the student's learning achievement in English, because learning motivation only contributed as much as $28.2 \%$, while the other variables have contributed as much as $71.8 \%$. Therefore, the existence of other factors must be developed for students to achieve success in learning achievement.

Calculation value of $F$ is based on calculation result on the ANOVA below table:

Table 6. ANOVA(b) Coefficient Correlation

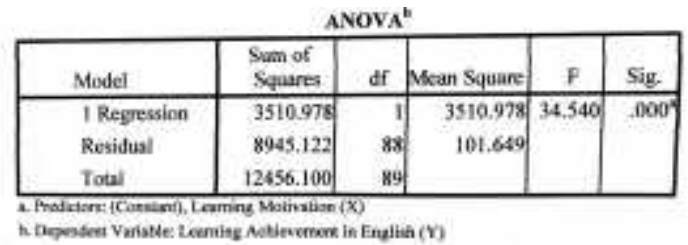

From the Sig-value $\quad=0.000$ is smaller than value of $\alpha=0.05$ and numerator $\mathrm{dk}=1, \quad \mathrm{dk}$ denominator 88 obtained value of $F_{\text {table }}=3.100$ further obtained value of $\mathrm{F}_{\text {count }}=34.540$.

By comparing both of two $F$ values obtained $\quad F_{\text {count }}=34.540 \quad$ is bigger than value of $F_{\text {table }}=3.100$ in order to be obtained conclusions reject $\mathrm{H}_{\mathbf{0}}$ and then accept $\mathrm{H}_{1}$. Thus obtained conclusion "There is a direct effects of student's learning motivation towards learning achievement in English".

\section{Testing Hypothesis}

The effects of learning motivation (X) towards student's learning achievement in English (Y) stated by the correlation coefficient achievement in English (Y) stated by the correlation coefficient $r$ as shown in the following table. From the results of calculations and analysis towards research data obtained the following coefficient values.

Table 7. Regression and Significance

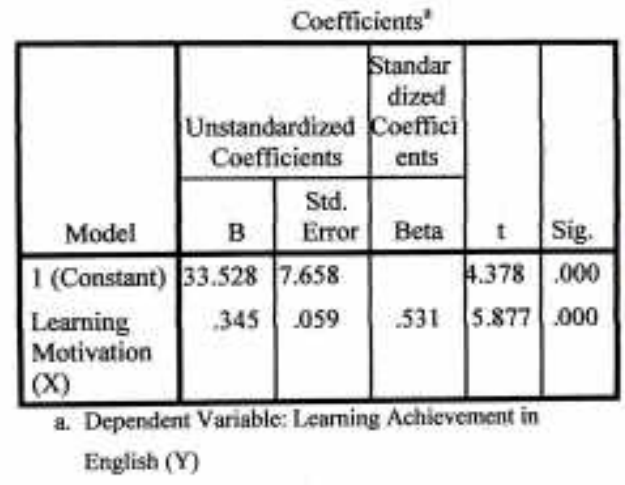

Based on the table shows that the statistical hypothesis $\mathrm{H}_{0}$ : state There is no effects of learning motivation (X) towards student's learning achievement in English (Y), is rejected because this can proved from the value of $\mathbf{t}_{\mathbf{0}}=5.877$ and sig $=0.000<0.05$. It means $\mathrm{H} 1$ is accepted. This means that research hypothesis states that there is significance effect of learning motivation (X) towards student's learning achievement in English (Y). Therefore, based on regression equation 
can be informed that each of increase in the quality of student's learning motivation as many as one unit, so at the same time, will

affect student's learning achievement in English as many as 0.345 .

From the coefficients table above obtained equation regression variable of $\mathrm{Y}$ on $\mathrm{X}$ is $\hat{\mathrm{Y}}$ $=33.528+0.345 \mathrm{X}$, the equation informs that each increase in learning motivation as much as one unit followed by a changes student's achievement in English as much as 0,345 with the constants 33.528 .

Based on this equation clearly that the existence of learning motivation has direct contribution towards achievement of changes student's achievement in English. The more positive learning motivation built by student will be more optimal to student's learning achievement in English which can be achieved.

\section{Discussion of Research Results}

Based on research data about the effects of learning motivation (X) towards learning achievement in English (Y), can be expressed as follows:

\section{The effect of Learning Motivation (X)} towards Students' Learning Achievement in English (Y).

Based on the results of data analysis, it is determined that learning motivation has a significant role in building students' learning achievement in English. The more positive learning motivation that will be possessed the optimal learning achievement also that can be achieved.

The effect of learning motivation is determined by the regression equation of $\mathrm{Y}$ variable, $\hat{\mathbf{Y}}=33.528+0.345 \mathrm{X}$, the equation is informs that each increase learning motivation as much as one unit followed by a change in students' learning achievement as many as 0.345 , by a constant 33.528 . Furthermore, the dependence of learning achievement towards learning motivation is also reflected from correlation coefficient $\mathrm{R}=0531$.

This coefficient informs that learning motivation has an influence towards students' achievement and $28.20 \%$ learning achievement determined by the learning achievement of each student. Therefore, there should be efforts to build learning motivation so that learning achievement can be improved.

The finding in accordance with the findings of the research, conducted prior with conclusion that, Strong and weak learning motivation also influence a person's learning success. Therefore, learning motivation should endeavored especially coming from within themselves by constantly thinking about a future full of challenges and must be overcome to achieve your goal. Continually set goals can be achieve by learning.

Suggested a number of ways to increase motivation of students without having to reorganize the class a massive: Use verbal language, use the test and value wise, arouse curiosity desire exploration doing extraordinary things, stimulate the desire for children, capitalize apperception students, apply the concepts or principles in the context of unique and extraordinary, ask the students to use terms that have been studied previously use simulations and games, minimize the appeal system as opposed to motivation, minimize consequences of the involvement of students in learning.

The research results also inform that there is a significant influence between motivation on student learning achievement. This means that if 
students have motivation in learning, then their learning achievements will be good (high). Conversely, if students have bad habits in learning, then their learning achievements will be bad or low.

\section{CONCLUSIONS}

Based on research data that has been described in the previous section and supported by statistical analysis can be made conclusions that here is significance effects of learning motivation towards learning achievement in English.

Learning motivation has given contribution towards the student's learning achievement in English.

Beyond learning motivation confirmed there are variety of other variables that have significant effects on the student's learning achievement in English, because learning motivation only contributed as many as several unit parts.Therefore, the existence of other factors must be developed for students to achieve success in learning achievement.

The quality of student's learning motivation as many as one unit, so at the same time, will affect student's learning achievement in English as many as several unit parts.

\section{Suggestion}

Based on the conclusions and the implication of research, put forward some suggestions namely many things can improve student's learning achievement in English done in the classroom, that is to advice.

The way, instilling learning motivation and in facing various problems. Planting of these motivations can assist students in increasing of learning achievement. This is evidenced by the results of the above study. Therefore, to improve student's learning achievement are good, the teacher should be able to motivate their students learn. Motivation or encouragement is needed to provide the "spirit" for doing an activity or occupation. To increase motivation, many things can be done, including by providing awards for students who excel and sanction for students who are always breaking the rules.

\section{REFERENCES}

Abdurrahman, $\mathrm{M}$ \& Sambas, A.M. (2011). Panduan praktis memahami penelitian, Bandung: CV Pustaka Setia.

Arikunto, S.(2002).Prosedur penelitian suatu pendekatan praktek. Jakarta: PT. Rineka Cipta.

Djamarah, S.B. (2008). Psikologi belajar, Edisi kedua Jakarta: PT. Rineka Cipta.

Djiwandono. (2006).Psikologi pendidikan. Jakarta: Grasindo

Hamdu, G \& Lisa, A. (2011). Pengaruh motivasi belajar siswa terhadap prestasi belajar IPA di sekolah dasar. Jurnal Penelitian Pendidikan 22 (1).

Nation, I.S.P \& Macalister, J. (2010). Language curriculum design. Ed 1st

New York:The Taylor \& Francis Group e-Library. (2006). Standar isi dan standar kelulusan tingkat SMP/MTs. Jakarta: PT. Binatama Raya Jakarta

Prayitno, S. (2010).Teknik mudah dan cepat melakukan analisis aata penelitian dengan SPSS dan tanya jawab ujian pendadaran, Edisi Pertama.Yogyakarta: Gava Media.

Purwanto. (2009). Evaluasi hasil belajar. Surakarta: Pustaka Belajar.

Soemanto,W. (2006). Psikologi pendidikan: Landasan kerja 
pemimpin pendidikan (Cetakan ke 5). Jakarta: Rineka Cipta

Supardi, U.S. (2012).Applikasi statistika dalam penelitian, buku statistika yang paling komprehensif,cetakan pertama,Jakarta: PT Ufuk Publising House 